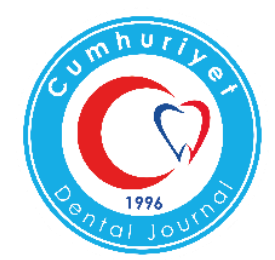

\title{
ORTHOGNATHIC TREATMENT OF A PATIENT WITH CLASS III MALOCCLUSION AND SEVERE FACIAL ASYMMETRY: REPORT OF A CASE
}

\author{
Sinı III Malokluzyon ve Şiddetli Fasiyal Asimetriye \\ Sahip Hastanin Ortognatik Cerrahi ile Tedavisi: Olgu Sunumu
}

Hande GÖRÜCÜ COŞKUNER ${ }^{1}$, İlken KOCADERELII ${ }^{1}$, Ersoy KONAŞ²

\author{
Makale Kodu/Article Code : 197202 \\ Makale Gönderilme Tarihi $\quad$ :28.07.2016 \\ Kabul Tarihi $\quad: 13.01 .2017$
}

\begin{abstract}
Aim: The aim of this case report was to present the orthognathic treatment of a patient with Class III malocclusion and severe asymmetry.
\end{abstract}

Subject and Method: The chief complaint of the 18-year old male was asymmetry. Clinically, he had maxillary retrognathism and severe facial asymmetry with the chin deviated to the left side. He also had a Class III molar and canine relationship. Cephalometric evaluation showed that the patient had maxillary retrusion and slight mandibular protrusion. The mandibular incisors were lingually and the maxillary incisors were labially inclined. Posteroanterior cephalometric analysis showed $2 \mathrm{~mm}$ maxillary and $5 \mathrm{~mm}$ mandibular midline deviation to the left side. The chin was deviated to the left side about $13^{\circ}$. After correction of the arch forms by fixed orthodontic treatment over seven months, surgical correction with bimaxillary osteotomy was undertaken.

Results: A Class I occlusion with normal overbite and overjet was achieved in 17 months. The maxillary retrusion, mandibular protrusion and asymmetry were corrected.

Conclusion: Combined orthodontic and orthognathic treatment resulted in a Class I occlusion and esthetically pleasing results.

Keywords: Facial asymmetry, Orthognathic treatment, Class III malocclusion

\section{öz}

Amaç: Bu olgu raporunun amacı Sınıf III malokluzyona ve şiddetli asimetriye sahip bir hastanın ortognatik tedavisini sunmaktır.

Birey ve Yöntem: 18 yaşında erkek hastanın esas şikayeti yüzündeki asimetrik görüntüdür. Klinik olarak maksiller retruzyonu, çene ucunda sola deviasyonu ve Sınıf III molar kanin ilişkisi bulunmaktadır. Sefalometrik değerlendirmeye göre maksiller retruzyonu ve hafif mandibular protruzyonu bulunmaktadır. Alt keserler dikleşmiştir, üst keserler labiale eğimlidir. Posteroanterior sefalometrik analizde sola doğru $2 \mathrm{~mm}$ maksiller, $5 \mathrm{~mm}$ mandibular orta hat kayması mevcuttur. Çene ucu $13^{\circ}$ sola kaymıştır. 7 ay süreyle uygulanan sabit ortodontik tedavi sonrası bimaksiller osteotomi ile cerrahi düzeltim sağlanmıştır.

Bulgular: 17 aylik tedavinin sonunda normal overbite, overjet ve Sınıf I okluzyon sağlanmıştır. Maksiller retruzyon, mandibular protruzyon ve asimetri düzeltilmiştir.

Sonuç: Kombine ortodontik ve ortognatik tedavi ile Sınıf I okluzyon elde edilmiş; kayıp estetik ve fonksiyon sağlanmıştır.

Anahtar kelimeler: Fasiyal asimetri, ortognatik tedavi, Sinıf III malokluzyon

\footnotetext{
${ }^{1}$ Department of Orthodontics, Faculty of Dentistry, Hacettepe University, Ankara, Turkey

${ }^{2}$ Department of Plastic Reconstructive and Aesthetic Surgery, Hacettepe University Medical School, Ankara Turkey
} 


\section{INTRODUCTION}

Facial asymmetry is a major esthetic problem and usually accompanies various types of malocclusions. Although there is minor asymmetry in every face, which is considered normal, ${ }^{1}$ closer facial symmetry is known to be an important factor in facial attractiveness. ${ }^{2,3}$

Facial asymmetry may accompany Class I malocclusion but frequently accompanies Class II or Class III malocclusions., ${ }^{4,5}$ Class III malocclusion can be characterized by maxillary retrusion, mandibular protrusion or both, and it has a $0 \%$ to $26 \%$ prevalence. ${ }^{6}$ Although dental asymmetries and minor skeletal asymmetries can be treated with orthodontic treatment alone, in patients with severe skeletal discrepancies, orthognathic surgery is recommended for esthetic and functional correction. ${ }^{5}$

This case report presents the orthognathic treatment of a patient with Class III malocclusion and severe skeletal asymmetry.

\section{CASE REPORT}

An 18-year-old male was referred to Hacettepe University Faculty of Dentistry Department of Orthodontics with a chief complaint of asymmetry. When he was a six-month-old baby, the doctors told his parents that there was a tissue deficiency on one side of his face. When he was 14 years old, he fell down stairs onto the right side of his face. Except for these issues, his medical history was unremarkable.

Clinically, he had maxillary retrognathism and severe facial asymmetry with the chin deviated to the left side. Intraorally, he had Class III molar and canine relationships. The upper and lower dental midlines were deviated to the left side with more deviation in the mandibular midline. (Figure 1)

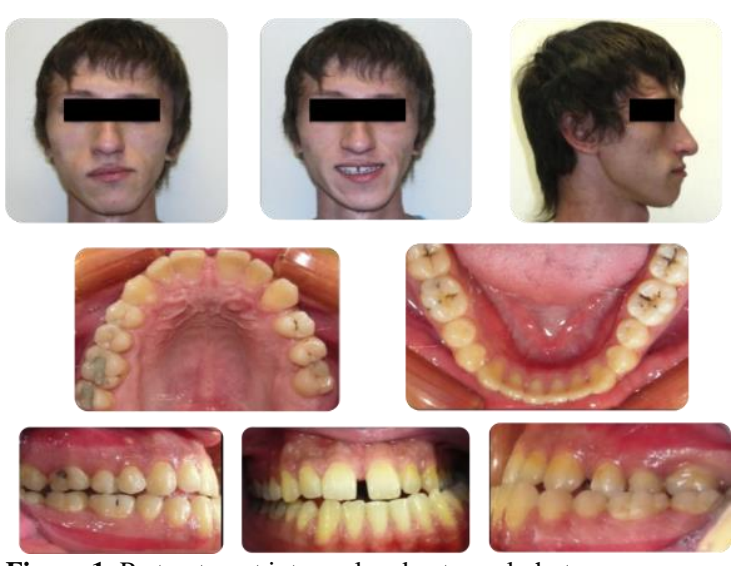

Figure 1. Pretreatment intraoral and extraoral photos

Panoramic x-ray evaluation showed that all permanent teeth were present except the upper left first molar, which had been extracted because of caries. The right mandibular condyle was thinner and longer in the panoramic view (Figure 2).

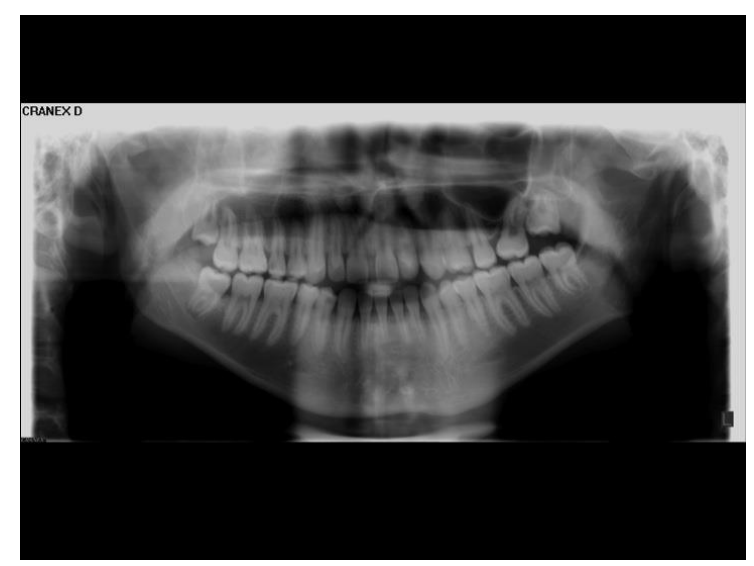

Figure 2. Pretreatment panoramic radiograph

Cephalometric evaluation showed that the patient had maxillary retrusion and slight mandibular protrusion with an ANB angle of $2^{\circ}$. The mandibular incisors were lingually and the maxillary incisors labially inclined. (Figure 3) Posteroanterior cephalometric analysis showed $2 \mathrm{~mm}$ maxillary and $5 \mathrm{~mm}$ mandibular midline deviation to the left side. The chin was deviated to the left side about $13^{\circ}$. (Figure 4) There was no crowding in the lower arch, and there was $6 \mathrm{~mm}$ excess space in the upper arch. 


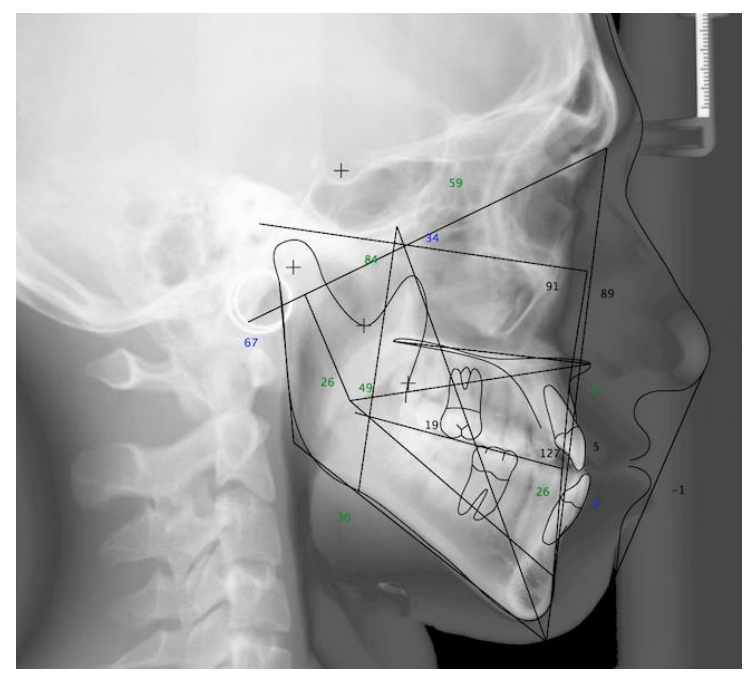

Figure 3. Pretreatment lateral cephalometric tracing

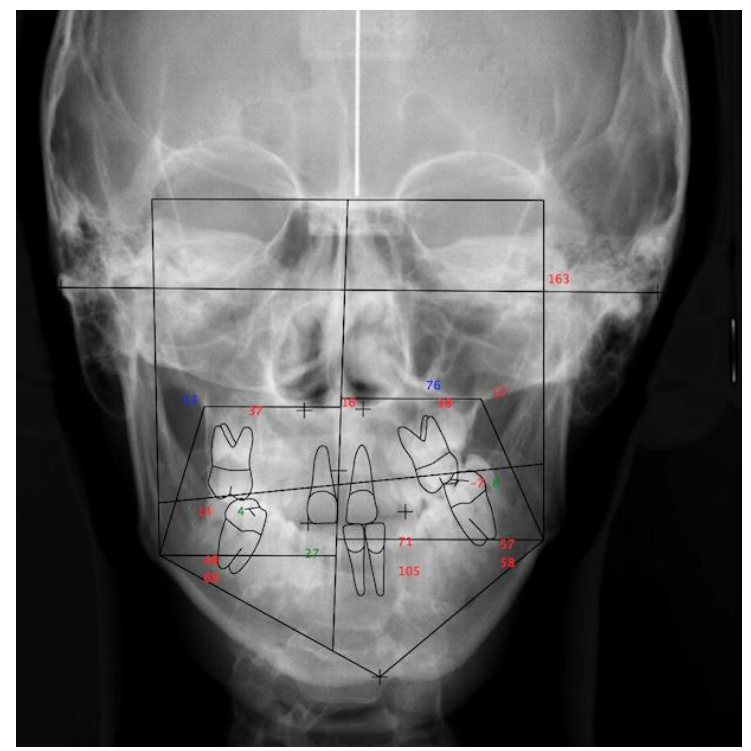

Figure 4. Pretreatment anteroposterior tracing

\section{Treatment Objectives}

Our goals were to improve the patient's facial esthetics and to provide functional occlusion. There was severe skeletal asymmetry and Class III malocclusion with both maxillary retrusion and mandibular protrusion, so the only treatment choice was bimaxillary orthognathic surgery after decompensation of the dental arches with fixed orthodontic treatment. Although the maxillary incisors were labially inclined, extraction of the upper premolars was not planned, as the slight labial inclination of the incisors was thought to be correctable with the aid of excessive space at the upper arch.

\section{Treatment Progress}

The upper and lower arches were bonded and banded with 0.018-inch Roth prescription brackets (Victory Series, 3M Unitek, Monrovia, Calif), and 0.014 nickel titanium (Ni-Ti), 0.016 $\mathrm{Ni}-\mathrm{Ti}, \quad 0.016$ stainless steel (SS) and $0.016 \times 0.016$ SS arch wires were inserted. Upper left canines, premolars and the molar were moved to the anterior one by one, using elastic chains for the space closure. Later, $0.016 \times 0.022$ SS arch wires were inserted and dental models were taken. As it was seen that the upper and lower dental models were consistent with each other after eight months of fixed orthodontic treatment, a surgical plan was devised.

\section{Surgical Procedures}

Two-jaw orthognathic surgery was planned to correct the maxillary retrusion and facial asymmetry. First, dental models of the patient were carried out to the articulator with face-bow transfer, and the model surgery was performed according to the surgical plan. Two pieces of acrylic splint were constructed at the laboratory. With Le Fort 1 osteotomy, the maxilla was moved forward by $1.5 \mathrm{~mm}$ at the right side and by $6.5 \mathrm{~mm}$ at the left side. The maxilla was fixed at the planned position with the aid of the acrylic splint. Asymmetric mandibular surgery was then performed by bilateral sagittal splint osteotomy with a $12 \mathrm{~mm}$ setback on the right side and $5 \mathrm{~mm}$ forward movement on the left side. Then the intermaxillary fixation was performed using elastics by using an acrylic splint. Postoperative intermaxillary fixation was maintained for four weeks. After five months of postsurgical orthodontics treatment, debonding was planned.

\section{Treatment Results}

Favorable facial changes were obtained. The facial asymmetry and Class III profile features were corrected. The upper left central incisors on the mesial side and the lower dental midline were coincident with the facial midline, and Class I molar and canine relationships were 
established. The patient's oral hygiene was poor, and he was referred for descaling and for diastema closure of the upper central incisors. Because both central incisors needed esthetic restoration for a symmetrical appearance, the upper midline became slightly deviated to the right side when the restorations were finished. (Figure 5)
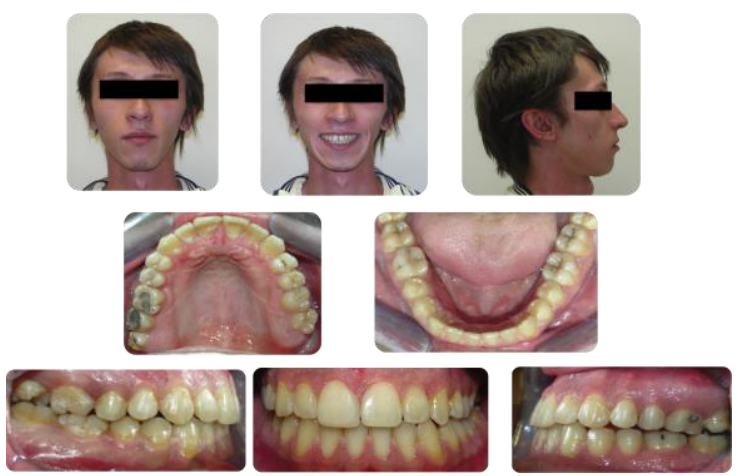

Figure 5. Posttreatment intraoral and extraoral photos

Cephalometrically, the SNA angle increased from $75^{\circ}$ to $79^{\circ}$, the SNB angle decreased from $77^{\circ}$ to $75^{\circ}$, and a skeletal Class I relationship was obtained with an ANB angle of $4^{\circ}$. The upper incisors were slightly retroclined from $118^{\circ}$ to $110^{\circ}$ at the upper incisor-Frankfurt horizontal angle, and lower incisor inclinations were not changed with the treatment. FMA angle slightly increased from $31^{\circ}$ to $35^{\circ}, 2.5 \mathrm{~mm}$ overjet and $1 \mathrm{~mm}$ overbite was obtained. (Table 1, Figure 6a, 6b, 6c)

Table 1. Pretreatment and posttreatment cephalometrical values

\begin{tabular}{|l|c|c|}
\hline VARIABLES & INITIAL & FINAL \\
\hline SNA $^{\circ}$ & $75^{\circ}$ & $79^{\circ}$ \\
\hline SNB $^{\circ}$ & $77^{\circ}$ & $75^{\circ}$ \\
\hline ANB $^{\circ}$ & $-2^{\circ}$ & $4^{\circ}$ \\
\hline MAXILLARY DEPTH $^{\circ}$ & $88^{\circ}$ & $90^{\circ}$ \\
\hline FMA $^{\circ}$ & $31^{\circ}$ & $35^{\circ}$ \\
\hline Mx1-FH $^{\circ}$ & $118^{\circ}$ & $110^{\circ}$ \\
\hline Mx1-NA $^{\circ}$ & $30^{\circ}$ & $20^{\circ}$ \\
\hline IMPA $^{\circ}$ & $79^{\circ}$ & $80^{\circ}$ \\
\hline Md1-NB $^{\circ}$ & $21^{\circ}$ & $24^{\circ}$ \\
\hline OVERJET $(\mathrm{mm})^{\circ}$ & $-2 \mathrm{~mm}$ & $2,5 \mathrm{~mm}$ \\
\hline OVERBITE $(\mathrm{mm})^{\circ}$ & $0 \mathrm{~mm}$ & $1 \mathrm{~mm}$ \\
\hline
\end{tabular}

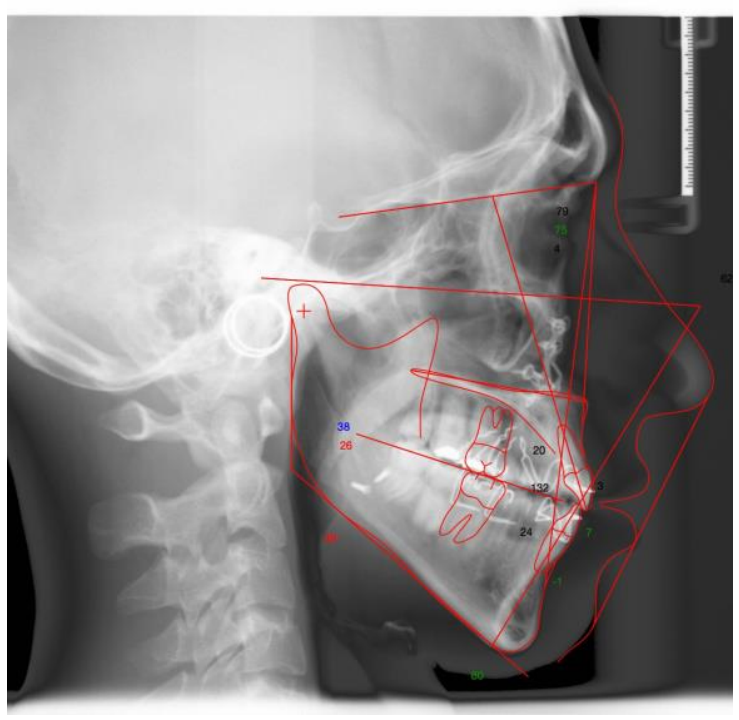

Figure 6a. Posttreatment lateral cephalometric tracing

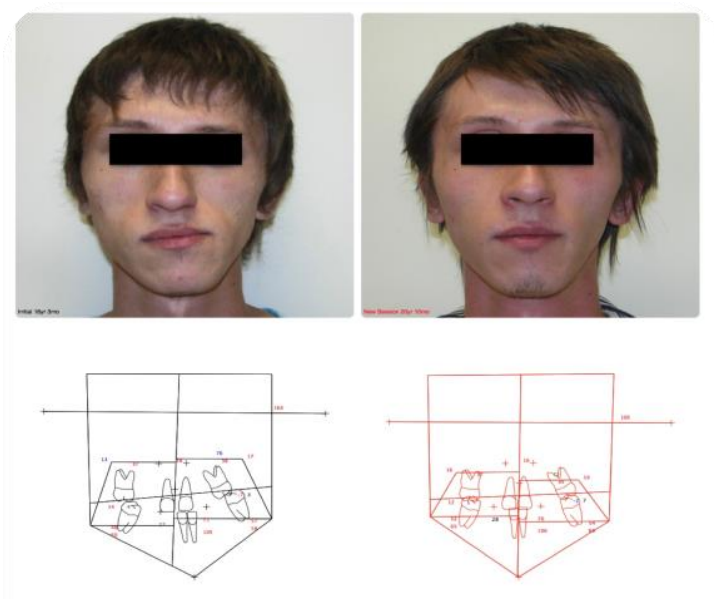

Figure 6b. Pretreatment and posttreatment anteroposterior tracings and photos

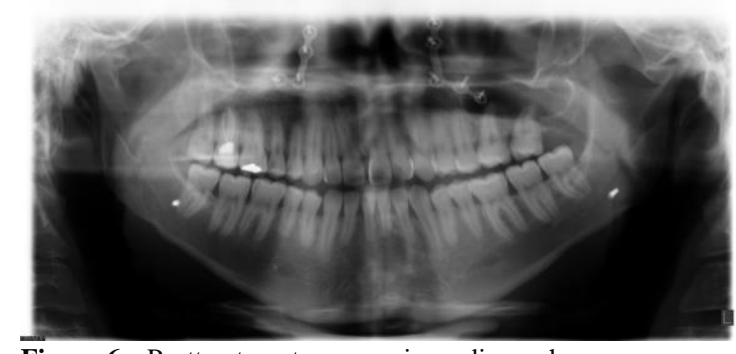

Figure 6c. Posttreatment panoramica radiograph

The superimpositions at profile, NasionBasion at CC, Nasion Basion at Nasion and Xi point-Pm at $\mathrm{Pm}$ are shown in Figure 7. It was seen that the profile improved noticeably, mandible was positioned more posteriorly and rotated clockwise and maxilla was moved anteriorly. 


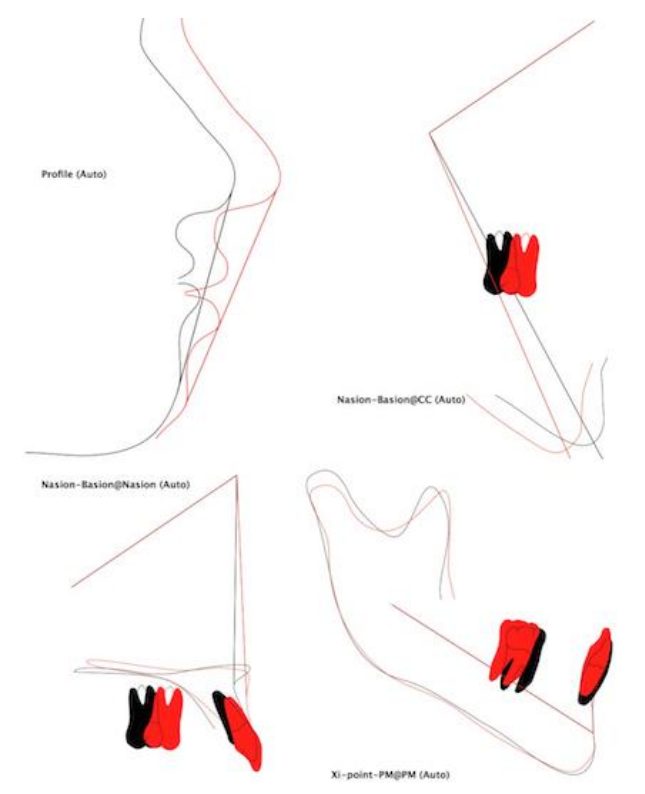

Figure 7. Pretreatment and posttreatment lateral cephalometric comparison

\section{DISCUSSION}

When a patient is seeking for a treatment for his dental and skeletal discrepancy, the first step should be the evaluation of the etiology as it mainly determines the treatment plan. The etiology of asymmetry can be divided into 3 main categories; congenital, developmental and acquired. ${ }^{7}$ Congenital asymmetries are usually associated with some syndromes but in our case although the patient had no syndrome, when he was a 6-month-old baby the asymmetry of his face was diagnosed as a tissue deficiency. The patient stated that the asymmetry increased gradually after he fell down from stairs so it was thought that the patient had a tissue deficiency from birth, but this severe facial asymmetry could be an acquired condition triggered by trauma. Also the patient's father had a Class III malocclusion, and the etiology of Class III malocclusion was thought as a genetic predisposition.

The panoramic radiograph of the patient revealed asymmetric condyles with right condyle being thinner and longer. In Class III malocclusion with mandibular deviation it was reported that the condylar morphology and the density of the deviated side differs from nondeviated side. ${ }^{8}$ But that asymmetric condition should be differentiated from condylar hyperplasia which is the overdevelopment of the condyle unilaterally or bilaterally and leads to facial asymmetry or mandibular deviation. ${ }^{9}$ When the patient was referred to our clinic, he was 15 years old and because of the asymmetric conditions of the condyles and his Class III malocclusion, the patient was followed up till he was 18 years old. As it is known that the orthognathic surgery should be planned after growth period ${ }^{10}$, we began to the treatment when it was observed that the severity of the discrepancy remains the same at one-year interval. The first step at pre-surgical orthodontic treatment was correction of decompensations. The inclinations of upper incisors were corrected and upper spaces were closed, but the inclinations of the mandibular incisors were not corrected as it could lead to reduced vertical alveolar height. ${ }^{11}$

Dentoalveolar compensations are common in patients with Class III malocclusions and should be corrected with orthodontic treatment before orthognathic surgery for adequate surgical correction. ${ }^{12,13}$ Capelloza et al..$^{14}$ suggested that decompensation of the maxillary arch satisfactorily leads to greater surgical correction. In the present case, although the upper incisors were labially inclined, there was also excessive space in the maxillary arch. So, instead of additional teeth extraction from the upper arch, the spaces were used for correction of the upper incisor inclinations.

Although orthognathic surgery is a difficult treatment plan for patients, in severe skeletal discrepancies, the patients seek orthognathic treatment choice for improvement in their esthetic appearance. Especially when the case is facial asymmetry, orthognathic treatment could be the only choice. It was shown that with double jaw orthognathic surgery facial symmetry improves and correlations of soft and hard tissue changes are highly predictable especially in mandibular region. ${ }^{15}$ Although the treatment length and surgical risks are major problems for the 
patients, the improvement in the appearance by orthognathic surgery usually satisfies the patients $^{16-18}$ and results in improvement in psychosocial adjustment. ${ }^{19}$ In our case, the patient was unhappy about his facial appearance and seeking for a treatment for the improvement in his appearance so after the treatment his selfesteem increased noticeably.

\section{CONCLUSIONS}

The combined orthodontic and orthognathic treatment of this patient with severe asymmetry and Class III malocclusion resulted in a Class I occlusion and esthetically pleasing results.

\section{REFERENCES}

1. Bishara SE, Burkey PS, Kharouf JG. Dental and facial asymmetries: a review. Angle Orthod. 1994;64(2):89-98.

2. Koehler N, Rhodes G, Simmons LW. Are human female preferences for symmetrical male faces enhanced when conception is likely? Anim Behav. 2002;64:233-8.

3. Rhodes G, Yoshikawa S, Clark A, Lee K, McKay R, Akamatsu S. Attractiveness of facial averageness and symmetry in non-western cultures: in search of biologically based standards of beauty. Perception. 2001;30(5):611-25.

4. Reyneke JP, Tsakiris P, Kienle F. A simple classification for surgical treatment planning of maxillomandibular asymmetry. $\mathrm{Br} \quad \mathrm{J}$ Oral Maxillofac Surg. 1997;35(5):349-51.

5. Cheong YW, Lo LJ. Facial asymmetry: etiology, evaluation, and management. Chang Gung Med J. 2011;34(4):341-51.

6. Hardy DK, Cubas YP, MF. O. Prevalence of Angle Class III malocclusion: a systematic review and meta-analysis. Open J Epidemiol. 2012;2:75-82.

7. Maheswari S, Verma SK, Gaur A, S. D. Diagnosis and management of facial asymmetries. J Orthod Res. 2015;3(2):81-7.
8. Wen L, Yan W, Yue Z, Bo D, Xiao Y, ChunLing W. Study of Condylar Asymmetry in Angle Class III Malocclusion With Mandibular Deviation. J Craniofac Surg. 2015;26(3):e264-8.

9. Mehrotra D, Dhasmana S, Kamboj M, Gambhir G. Condylar hyperplasia and facial asymmetry: report of five cases. J Maxillofac Oral Surg. 2011;10(1):50-6.

10.Weaver N, Glover K, Major P, Varnhagen C, Grace M. Age limitation on provision of orthopedic therapy and orthognathic surgery. Am J Orthod Dentofacial Orthop. 1998;113(2):156-64.

11.Sun B, Tang J, Xiao P, Ding Y. Presurgical orthodontic decompensation alters alveolar bone condition around mandibular incisors in adults with skeletal Class III malocclusion. Int J Clin Exp Med. 2015;8(8):12866-73.

12. Troy BA, Shanker S, Fields HW, Vig K, Johnston W. Comparison of incisor inclination in patients with Class III malocclusion treated with orthognathic surgery or orthodontic camouflage. Am J Orthod Dentofacial Orthop 2009;135(2):146 e1-9.

13.Johnston C, Burden D, Kennedy D,

Harradine N, Stevenson M. Class III surgical orthodontic treatment: a cephalometric study. Am J Orthod Dentofacial Orthop 2006;130:300-9.

14. Capelozza Filho L, Martins A, Mazzotini R, da Silva OG. Effects of dental decompensation on the surgical treatment of mandibular prognathism. Int J Adult Orthod Orthognath Surg 1996;11:165-80.

15.Wermker K, Kleinheinz J, Jung S, Dirksen D. Soft tissue response and facial symmetry after orthognathic surgery. J Craniomaxillofac Surg. 2014;42(6):e339-45.

16. Magro-Filho O, Goiato MC, Oliveira DT, Martins LP, Salazar M, Medeiros RA, et al. Evaluation of Patients' Satisfaction after Class III Orthognathic Surgery. J Clin Diagn Res. 2015;9(10):ZC23-7. 
17.Asada K, Motoyoshi M, Tamura T, Nakajima A, Mayahara K, Shimizu N. Satisfaction with orthognathic surgery of skeletal Class III patients. Am J Orthod Dentofacial Orthop. 2015;148(5):827-37.

18.Pacheco-Pereira C, Abreu LG, Dick BD, De Luca Canto G, Paiva SM, Flores-Mir C. Patient satisfaction after orthodontic treatment combined with orthognathic surgery: A systematic review. Angle Orthod 2016;86(3):495-508.

19.Lazaridou-Terzoudi T, Kiyak HA, Moore R, Athanasiou AE, Melsen B. Long-term assessment of psychologic outcomes of orthognathic surgery. J Oral Maxillofac Surg 2003;61(5):545-52.

\section{Correspondence Author}

Hande GÖRÜCÜ COŞKUNER

Hacettepe University

Faculty of Dentistry

Department of Orthodontics

Sihhiye, 6100,

Ankara / Turkey

Phone: +90 3123052290

Fax: +90 3123091138

E-mail: hande.gorucu@hotmail.com 